\title{
Spatial and seasonal heterogeneity of sea ice microbial communities in the first-year ice of Terre Adélie area (Antarctica)
}

\author{
Michel Fiala $^{1, *}$, Harri Kuosa ${ }^{2}$, Elżbieta E. Kopczyńska ${ }^{3}$, Louise Oriol ${ }^{1}$, Daniel Delille ${ }^{1}$ \\ ${ }^{1}$ Observatoire Océanologique, Universite P. et M. Curie, UMR-CNRS 7621, 66651 Banyuls-sur-mer cedex, France \\ ${ }^{2}$ Finnish Institute of Marine Research, POB 33, 00931 Helsinki, Finland \\ ${ }^{3}$ Department of Antarctic Biology, Polish Academy of Sciences, Ustrzycka 10/12, 02141 Warszawa, Poland
}

\begin{abstract}
Spatial and temporal changes in sea ice microbial communities were investigated at 4 stations located along a south-north transect on the land-fast ice of Dumont d'Urville station area (Adélie Land, $66^{\circ} 40^{\prime} \mathrm{S}, 141^{\circ} 01^{\prime} \mathrm{E}$ ) during the ice coverage period (April to December). A seasonal pattern was observed in microalgae, bacteria and protozoan abundance distribution. A maximum chlorophyll a concentration occurred during fall ice formation in the surface layer with the highest values at the near-shore station (100 to $215 \mu^{-1} \mathrm{l}^{-1}$ ). A second maximum was observed before ice breaking in the bottom ice $\left(50\right.$ to $\left.90 \mu \mathrm{g} \mathrm{l}^{-1}\right)$. Microalgal communities were dominated by diatoms ( $>86 \%$ of the total cells), mainly represented by Fragilariopsis, Nitzschia, Navicula and Pseudonitzschia species. Fragilariopsis curta was the dominant species during the first bloom whereas Fragilariopsis cylindrus, Nitzschia longissima and Tropidoneis sp. were the main contributors during the second bloom at the bottom ice core. Maximum protozoan abundance was recorded during the fall bloom in the surface layer with dominance of ciliates, which contributed more than $75 \%$ of total cell numbers. During this period, the maximum ciliate abundance was associated with the maximum bacteria and diatom numbers and microalgal biomass. The dramatic decrease of the ice algal biomass from south to north paralleled that of the underlying water phytoplankton available for new ice incorporation. The spatial algal biomass decrease could explain the parallel decrease in the abundance of bacteria and heterotrophic ciliates through trophic interactions.
\end{abstract}

KEY WORDS: Antarctica $\cdot$ Land-fast ice $\cdot$ Microbial communities $\cdot$ Chlorophyll a $\cdot$ Nutrients

\section{INTRODUCTION}

Sea ice is recognized to be a dynamic and complex habitat for microbial communities that show high spatial and temporal variabilities. In the Southern Ocean, the circumpolar extent of sea ice varies from 5 to 20 million $\mathrm{km}^{2}$ seasonally (Maykut 1985, Legendre et al. 1992). Antarctic sea ice represents one of the largest and most dynamic ecosystems of the world ocean. During initial ice growth, microbial communities are incorporated into several distinct microhabitats of sea ice (Horner et al. 1988). These so-called sympagic organisms consist of both autotrophic and heterotrophic assemblages. They are characterized by seasonal and spatial variations with regard to their composition, dis- tribution and abundance (Horner et al. 1992, Ackley \& Sullivan 1994, Archer et al. 1996). The spatial and temporal variations of sea ice communities suggest an active food web within the ice, channeling algal production to bacteria and protozoa (Stoecker et al. 1998, 2000, Delille et al. 2002). Sea ice algae are estimated to contribute ca. $24 \%$ of the total biogenic carbon produced in the ice-covered Southern Ocean (Legendre et al. 1992). The highest biomass of algae occurs near the bottom of fast ice and in platelet ice (Ackley et al. 1979). In fast ice, which occupies 1 to $5 \%$ of the total ice cover area around Antarctica, the algal standing crop is 3 orders of magnitude higher than in pack ice (Ackley \& Sullivan 1994). Diatoms are generally the dominant group, with the highest microalgal biomass 
(Watanabe et al. 1990, Garrison \& Buck 1991, Archer et al. 1996, McMinn 1996, Moro et al. 2000, Riaux-Gobin et al. 2000). However, phytoflagellates are often dominant during spring in the upper sea ice (Stoecker et al. 1997, 1998). Sea ice contains a wide variety of bacterial assemblages. Most bacteria isolated from sea ice have been found to be pigmented and highly coldadapted, with both free-living and epiphytic bacteria present (Grossi et al. 1984). Most taxa isolated from sea ice belong to the $\gamma$-proteobacteria and the CytophagaFlavobacterium-Bacteroides division (Bowman et al. 1997, Gozink et al. 1998, Junge et al. 1998, Nichols et al. 1999, Reddy et al. 2002). 16S rDNA clone library analysis corroborated these culture data (Brown \& Bowman 2001). Heterotrophic protozoa are also present in sea ice (Garrison \& Buck 1991, Stoecker et al. 1993, Delille et al. 2002, Song \& Wilbert 2002) and are mainly composed of ciliates, nanoflagellates and dinoflagellates (Archer et al. 1996, Garrison et al. 2005). They play a major role in the removal of algal and bacterial biomass in Antarctic waters (Becquevort et al. 2000, Caron et al. 2000, Vaqué et al. 2004). Despite the lack of data on the consumption rate of bacterial and algal production by heterotrophic protozoa, some indirect measurements or extrapolations suggest that protozoan grazing plays an important role in sea ice (Garison \& Buck 1991, Garison et al. 1993, Archer et al. 1996). Few studies address the abundance and biomass of the 3 components of the microbial loop in the sea ice (Archer et al. 1996). Generally,

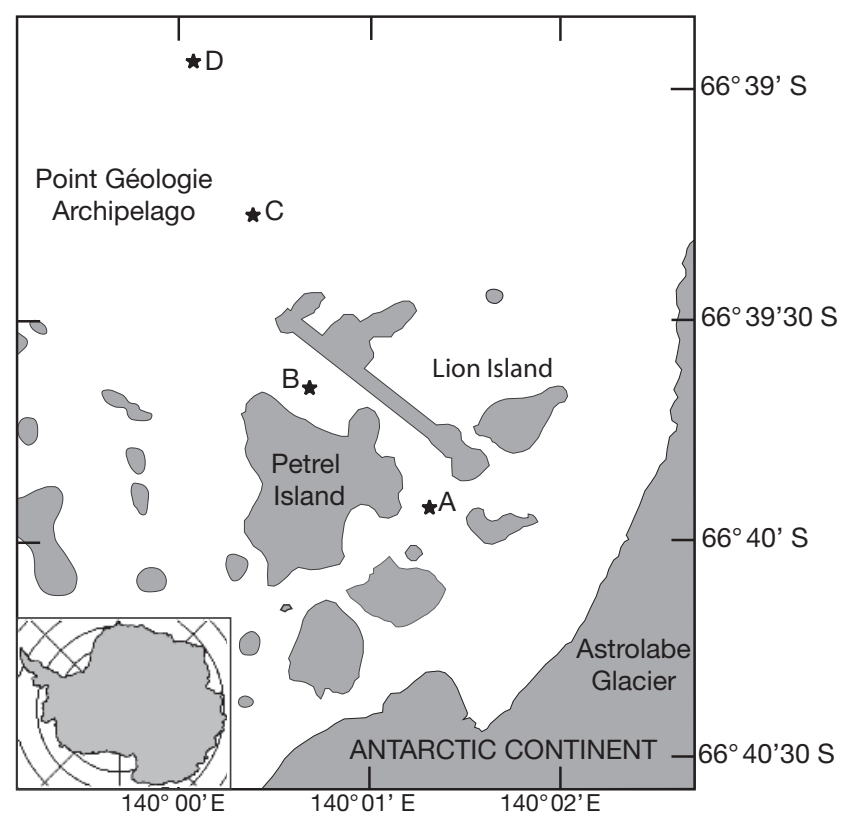

Fig. 1. Location of the 4 sampling stations (Stns A, B, C and D) at the Pointe Géologie Archipelago, Terre Adélie, Antarctica autotrophic biomass is dominant in sea ice. In the fast ice of Adélie Land it contributed on average $80.6 \%$ of the total biomass whereas bacterial and protozoan biomass accounted for only 16.4 and $3 \%$, respectively (Delille et al. 2002).

Due to the difficulties of accessing the ice environment during ice formation and in the polar winter night, little is known about the spatial and seasonal distribution and composition patterns of the microbial assemblage in sea ice. Most of the previous studies on ice microbial communities distribution have been focused on short-term observations in limited near-shore regions (Watanabe at al. 1990, Archer et al. 1996). The purpose of the present work was to examine spatial and temporal heterogeneity of sea ice microbial communities inhabiting first-year ice at 4 stations located along a south-north transect in the Dumont d'Urville station area.

\section{MATERIALS AND METHODS}

The study was conducted during the sea ice period from April to December 1998 in the Pointe Géologie Archipelago close to the French Antarctic station of Dumont d'Urville (Adélie Land, 66 $46^{\circ} \mathrm{S}, 141^{\circ} 01^{\prime} \mathrm{E}$ ). Sampling was carried out at 4 stations chosen for their accessibility throughout the ice season (Fig. 1). They were located along a south-north transect. Stn A corresponded to the zone previously investigated (Delille et al. 2002). It was located $500 \mathrm{~m}$ offshore in the middle of the channel between the main islands of the archipelago (20 m depth). Stn D corresponded to the deepest zone $(100 \mathrm{~m})$ that could be reached safely in wintertime. The other intermediate stations (Stns B and C) were chosen in order to achieve a regular distribution along the study transect. Sampling was carried out from April to mid-December at Stn A (16 samples) and Stn B (13 samples), from the end of April to the beginning of December at Stn C (12 samples), and from June to mid-November at Stn D (7 samples).

Ice samples were collected in a homogeneous and solid layer of fast ice using $10 \mathrm{~cm}$ (internal diameter) ice-coring augers. Core-horizons were cut vertically into $20 \mathrm{~cm}$ segments with a sterile blade. To avoid contamination from the ice-auger, subsamples were taken from the centre of these segments, weighed, and stored in a cool sterile glass box prior to melting. Subsamples were gently melted in a known volume of sterile artificial seawater composed of $30 \mathrm{~g} \mathrm{l}^{-1} \mathrm{NaCl}$ dissolved in filtered distilled water. This dilution technique reduces osmotic shock and cell loss. Following melting in the dark at $4^{\circ} \mathrm{C}$ for ca. $24 \mathrm{~h}$, fixatives were added to specific subsamples. Bacterial samples for total bacterial counts were preserved with particle-free 
formaldehyde (ca. $4 \%$ final concentration). Protozoan samples were preserved with $1 \%$ acid Lugol's iodine solution and algal samples with formalin (final concentration ca. $0.4 \%$ ). Samples were stored in the dark at room temperature until laboratory analysis.

Melt samples were filtered through Whatman GF/F glass fiber filter under low vacuum (<5 mm $\mathrm{Hg})$. Nitrate, silicic acid and orthophosphate were determined using a standard automated method (Tréguer \& Le Corre 1975). Due to the absence of salinity and temperature measurements, the nutrient concentrations were not normalized.

Chlorophyll a (chl a) was extracted with 90\% acetone and their concentrations measured using a Perkin Elmer MPF 66 spectrofluorometer (Neveux \& Panouse 1987).

For taxonomic analysis and enumeration of algal communities, aliquots of $100 \mathrm{ml}$ were collected once a month at Stn $\mathrm{C}$ from different parts of the ice cores. Algal cells were counted using an Olympus inverted microscope according to procedures described by Utermöhl (1958). Larger micro-sized (>20 $\mu \mathrm{m}$ ) heterotrophic dinoflagellates (e.g. Gyrodinium, Protoperidinium) were identified on the basis of literature descriptions; however, only total dinoflagellate counts at $\mathrm{Stn} \mathrm{C}$ are presented in this paper.

Protozoa were identified and enumerated with inverted microscopy (Utermöhl 1958). Subsamples (50 ml) were allowed to settle for $24 \mathrm{~h}$ and the whole cell counting was done with a Leitz Diavert microscope with $\times 25$ and $\times 40$ objectives and phase contrast illumination. This technique is suitable for the enumeration of ciliates, dinoflagellates and euglenophytes, but small $(<10 \mu \mathrm{m})$ heterotrophic flagellates cannot be differentiated from autotrophs. All naked ciliates and total dinoflagellates were counted in size-classes with $10 \mu \mathrm{m}$ intervals.

Total bacteria were enumerated by epifluorescence microscopy (Hobbie et al. 1977). Direct counts (AODC) were performed using an Olympus BHA microscope with acridine orange staining onto a $0.2 \mu \mathrm{m}$ pore size black Nuclepore filter. A minimum of 500 fluorescing cells with a clear outline and definite cell shape were counted under oil immersion $(\times 1000)$ in a minimum of 10 randomly chosen fields. The number of viable psychrotolerant aerobic heterotrophic microorganisms in each sea ice sample was estimated using the spread plate technique on Nutrient Agar 2216 (Oppenheimer $\&$ ZoBell 1952). Inoculated plates (6 replicates) were incubated for $20 \mathrm{~d}$ at $4{ }^{\circ} \mathrm{C}$. Heterotrophic counts (colony forming units, CFU) are only representative of culturable bacteria, however, they are an useful bacterial indicator corresponding to a small group of active bacteria that react immediately to changes in their nutrient supply (Delille \& Bouvy 1989, Rheinheimer et al. 1989).
In addition, chl $a$ and inorganic nutrients concentrations were measured on surface underlying sea water samples collected by opening a sterile glass bottle at each station.

\section{RESULTS}

In Adélie Land, a land-fast ice cover develops each year from March-April to December. The ice thickness increases from a few centimeters to a maximum of ca. $2 \mathrm{~m}$. In mid-January the ice cover begins to melt and breaks suddenly. Residual ice floes are then pushed away. Due to direct exposure to strong catabatic winds the snow cover is generally very thin $(<2 \mathrm{~cm})$. Thus the snow cover thickness could be considered as relatively negligible during the present study. An intense temporal variability in air temperature and solar irradiation occurs in Antarctic. During the study period, air temperature ranged from a maximum of $-5^{\circ} \mathrm{C}$ during summer to a minimum of $-30^{\circ} \mathrm{C}$ during winter and solar irradiation varied from $0.01 \mathrm{~kJ} \mathrm{~cm}^{-2}$ in June to $2.8 \mathrm{~kJ}$ $\mathrm{cm}^{-2}$ in November-December.

Concentrations of inorganic nutrients in the fast ice changed dramatically during the study period. Mean nitrate concentrations in the entire ice column varied from 4.0 at Stn A to 5.4 at Stn D. The highest mean values were observed from April to July at Stns A, B and $\mathrm{C}$ and between July and August at Stn D (Table 1). Maximum nitrate concentrations (10 to $12 \mu \mathrm{mol} \mathrm{l^{-1 }}$ ) were observed in the bottom ice in May-June at Stns A, B and C and in July-August at Stn D. Phosphate mean concentrations ranged from $<1$ to $3.6 \mu \mathrm{mol} \mathrm{l}^{-1}$ and their seasonal distribution did not show noticeable variability at the 4 stations (Table 1). At Stn A, the mean concentrations were high (1.3 to $3.6 \mu \mathrm{mol} \mathrm{l^{-1 }}$ ) throughout the study period. At the 3 other stations, the mean values were $<1.5 \mu \mathrm{mol} \mathrm{l}^{-1}$. Like phosphate distribution, silicic acid did not show a well defined seasonal pattern at the 4 stations. Mean concentrations reached very high levels over the study area (22.7 to $121.5 \mu \mathrm{mol} \mathrm{l^{-1 }}$; Table 1). Maximum values (>100 $\mu \mathrm{mol}$ $1^{-1}$ ) were generally observed in the ice bottom layer.

In the surface underlying water, mean nutrient concentrations were higher than in the sea ice (data not shown). Orthophosphate and nitrate values were 2 and 6 -fold higher in underlying seawater than in sea ice cores, respectively, while silicic acid concentrations were equivalent.

In sea ice, chl a concentrations showed spatial and temporal distribution. The pigment biomass reached highest values at the near-shore Stn A and the lowest values at the offshore Stn D (Fig. 2). At Stn A, highest chl a concentrations (100 to $215 \mu \mathrm{g} \mathrm{l}^{-1}$ ) were encountered at the beginning of ice formation in the surface 
Table 1. Monthly mean concentrations of nitrate, phosphate and silicate in the entire sea ice column at the 4 study stations. $n d=$ no data

\begin{tabular}{|c|c|c|c|c|c|c|}
\hline \multirow[t]{2}{*}{ Month } & \multicolumn{2}{|c|}{ Nitrate $(\mu \mathrm{M})$} & \multicolumn{2}{|c|}{ Phosphate $(\mu \mathrm{M})$} & \multicolumn{2}{|c|}{ Silicate $(\mu M)$} \\
\hline & Mean & Range & Mean & Range & Mean & Range \\
\hline \multicolumn{7}{|l|}{ Stn A } \\
\hline Apr & 4.71 & $1.9-7.5$ & 3.62 & $1.0-6.3$ & 52.49 & $21.5-102.2$ \\
\hline May & 5.21 & $2.0-8.0$ & 2.68 & $0.9-5.5$ & 73.08 & $49.2-105.1$ \\
\hline Jun & 4.78 & $2.0-10.2$ & 3.32 & $1.3-7.3$ & 54.89 & $21.9-150.9$ \\
\hline Jul & 4.07 & $1.9-7.1$ & 2.73 & $0.7-6.4$ & 47.15 & $33.5-64.1$ \\
\hline Aug & \multicolumn{2}{|c|}{ nd } & \multicolumn{2}{|c|}{ nd } & \multicolumn{2}{|r|}{ nd } \\
\hline Sep & 3.94 & $1.8-7.0$ & 3.22 & $0.9-6.5$ & 58.58 & $25.5-103.1$ \\
\hline Oct & 3.97 & $1.7-8.2$ & 3.52 & $0.9-10.2$ & 43.03 & $29.9-93.1$ \\
\hline Nov & 2.99 & $2.6-4.1$ & 2.33 & $0.7-5.4$ & 48.38 & $12.4-87.1$ \\
\hline Dec & 2.20 & $1.4-3.5$ & 1.28 & $0.5-2.9$ & 57.18 & $43.8-73.9$ \\
\hline \multicolumn{7}{|l|}{ Stn B } \\
\hline Apr & 7.11 & $5.8-8.2$ & 1.53 & $0.9-2.3$ & 22.71 & $16.4-29.4$ \\
\hline May & 5.32 & $2.0-11.1$ & 0.96 & $0.4-1.7$ & 30.14 & $13.4-80.4$ \\
\hline Jun & 5.18 & $2.2-10.2$ & 0.91 & $0.4-1.8$ & 62.39 & $27.2-156.0$ \\
\hline Jul & 4.66 & $2.2-6.9$ & 0.74 & $0.5-1.0$ & 92.24 & $52.1-130.1$ \\
\hline Aug & 4.26 & $2.1-7.8$ & 1.23 & $0.6-2.4$ & 59.64 & $40.2-92.8$ \\
\hline Sep & 3.85 & $2.2-5.6$ & 0.67 & $0.5-0.9$ & 32.26 & $21.9-38.4$ \\
\hline Oct & 3.24 & $1.7-6.8$ & 0.53 & $0.3-1.1$ & 53.18 & $38.4-112.4$ \\
\hline Nov & 3.94 & $2.3-9.9$ & 1.15 & $0.5-2.2$ & 51.22 & $20.6-155.2$ \\
\hline Dec & 2.81 & $1.9-3.7$ & 0.87 & $0.4-2.9$ & 68.5 & $57.9-79.9$ \\
\hline \multicolumn{7}{|l|}{ Stn C } \\
\hline Apr & 4.99 & $3.9-7.0$ & 1.37 & $1.2-1.5$ & 24.60 & $20.1-27.2$ \\
\hline May & 5.65 & $1.9-10.7$ & 0.89 & $0.6-1.4$ & 43.67 & $29.4-68.1$ \\
\hline Jun & 6.07 & $3.0-10.8$ & 0.91 & $0.4-2.2$ & 82.04 & $36.2-107.7$ \\
\hline Jul & 4.08 & $1.7-5.7$ & 0.78 & $0.6-0.9$ & 41.70 & $32.3-59.6$ \\
\hline Aug & 3.89 & $1.9-5.1$ & 2.82 & $0.8-3.2$ & 59.24 & $39.0-85.4$ \\
\hline Sep & 4.41 & $2.2-6.5$ & 0.90 & $0.7-1.2$ & 74.72 & $32.4-134.7$ \\
\hline Oct & 3.33 & $1.9-6.5$ & 0.91 & $0.7-1.3$ & 99.00 & $88.8-114.2$ \\
\hline Nov & 3.26 & $2.9-4.2$ & 0.97 & $0.5-1.3$ & 46.04 & $39.7-54.7$ \\
\hline Dec & 2.44 & $1.9-3.7$ & 1.31 & $0.6-3.9$ & 60.67 & $50.0-70.4$ \\
\hline \multicolumn{7}{|l|}{ Stn D } \\
\hline Jun & 7.24 & $6.5-8.5$ & 1.09 & $1.0-1.2$ & 35.29 & $23.1-47.4$ \\
\hline Jul & 7.16 & $3.4-12.4$ & 1.48 & $1.0-2.3$ & 80.80 & $26.9-139.6$ \\
\hline Aug & 5.68 & $4.2-10.7$ & 0.91 & $0.7-1.2$ & 55.24 & $28.2-94.4$ \\
\hline Sep & 4.42 & $2.9-7.3$ & 0.86 & $0.6-1.2$ & 33.95 & $27.3-39.3$ \\
\hline Oct & 3.96 & $2.3-6.5$ & 0.57 & $0.4-0.9$ & 121.51 & $86.0-261.9$ \\
\hline Nov & 3.86 & $2.1-7.5$ & 0.66 & $0.4-1.2$ & 58.40 & $40.6-81.8$ \\
\hline
\end{tabular}

concentration was recorded at Stn A $\left(200.7 \mathrm{\mu g}^{-1}\right)$. The maximum values were lower at Stns B and C (156.3 and $166.5 \mu \mathrm{g}$ $\left.\mathrm{l}^{-1}\right)$, and $\operatorname{Stn} \mathrm{D}\left(38.6 \mu \mathrm{g} \mathrm{l}^{-1}\right)$.

At Stn C, total cell concentrations ranged, throughout the entire period, from 1.1 to $6.7 \times 10^{6}$ cells $\mathrm{l}^{-1}$ in the surface layer $(0$ to $20 \mathrm{~cm}$ ) of the ice core to 1.2 to $14.3 \times 10^{6}$ cells $\mathrm{l}^{-1}$ in the 60 to $140 \mathrm{~cm}$ stratum). The high cell densities $\left(>10^{6}\right.$ cells $\left.\mathrm{l}^{-1}\right)$ in deeper $(>40 \mathrm{~cm})$ parts of the ice core were present throughout the study period, but a maximum $\left(>13 \times 10^{6}\right.$ cells $\mathrm{l}^{-1}$ ) was found in May and June at 60 to $100 \mathrm{~cm}$. In all months at different ice core levels, diatoms formed 86.4 to $99.1 \%$ of the total cells (Fig. 4a); however, there were a few exceptions at the surface in May, June, and October, when they contributed 29 to $64 \%$ of the total cells. Dinoflagellates, both heterotrophic and autotrophic, were either not found (as in May), or formed only 0.3 to $3.3 \%$ of the total cells (Fig. 4b). Exceptionally, between 100 and $140 \mathrm{~cm}$ in November they made up $7.8 \%$ of the cells and displayed a maximum of 5.7 to $6.2 \times 10^{4}$ cells $\mathrm{l}^{-1}$. Total nanoflagellates, which included Prymnesiophytes, Prasinophytes, and 4 to $10 \mu \mathrm{m}$ monads, usually formed $<5 \%$ (Fig. 4c); only in October and November they contributed 28 to $50 \%$ between 20 and $60 \mathrm{~cm}$. The highest numbers $\left(5.6\right.$ to $6.6 \times 10^{5}$ cells $\mathrm{l}^{-1}$ ) were observed at 40 to $80 \mathrm{~cm}$ in November. Diatoms, the prevalent algae in the ice flora assemblage, were represented mainly by a few pennate species of the genera Fragilariopsis, Nitzschia, Navicula and Pseudo-nitzschia (Fig. 5). It is

layer. Thereafter a regular decrease occurred until ice breaking. A second chl a maximum (50 to $90 \mu \mathrm{g} \mathrm{l}^{-1}$ ) was observed just before ice melting at the bottom ice. The same seasonal pattern was observed at Stns B and $\mathrm{C}$ with lower maximum chl a values of $50 \mathrm{\mu g} \mathrm{l}^{-1}$ in April and 10 to $40 \mathrm{\mu g} \mathrm{l}^{-1}$ in November. At Stn D, the concentrations were low $\left(\leq 2 \mu \mathrm{g} \mathrm{l}^{-1}\right)$ throughout the icecovered period, except a maximum of $30 \mu \mathrm{g} \mathrm{l}^{-1}$ at the bottom ice in November.

In the surface underlying seawater, chl a concentrations showed the same spatial and seasonal pattern as in ice at the 4 stations. During autumn ice formation, maximum chl a values were 8.8, 0.44, 0.49 and $0.03 \mu \mathrm{g}$ $\mathrm{I}^{-1}$, at Stns A to D, respectively (Fig. 3). During winter, the values decreased and were $<0.2 \mu \mathrm{g} \mathrm{l}^{-1}$. A second peak was observed in November. The highest chl $a$ interesting to note that in July and in October-November samples obtained especially in the lower ice core parts $(60$ to $100 \mathrm{~cm}$ ), but also at the surface (July, November), contained about 60 to $98 \%$ of empty frustules of Fragilariopsis curta and F. cylindrus. On the other hand, in May, June and September, only full, young cells were found of chiefly F. curta. F. cylindrus and $F$. curta were the overall dominant diatoms along the ice core; the former species was more numerous in the 40 to $60 \mathrm{~cm}$ layer, while the latter at the bottom of the ice, mainly in May and June (Fig. 5). In the upper parts of the ice column where the lowest cell densities $\left(<0.4 \times 10^{4}\right.$ cells $\left.{ }^{-1}\right)$ were observed, 2 other species, Nitzschia longissima and N. closterium, were relatively abundant in most months (Fig. 5). In July, when none, or very few, live cells of $F$. curta were found in the sur- 

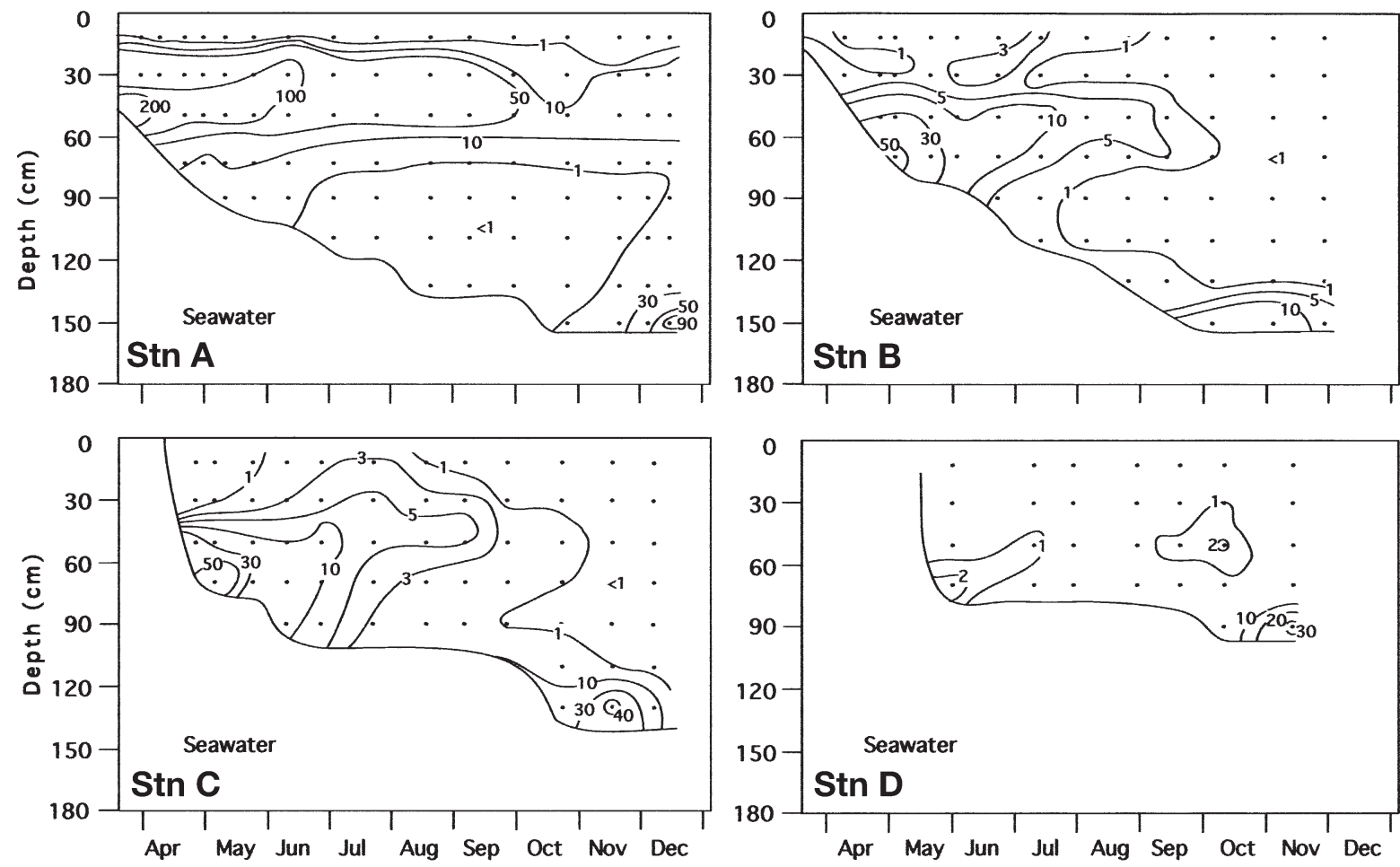

Fig. 2. Vertical distributions of chlorophyll a concentration $\left(\mu \mathrm{g} \mathrm{l}^{-1}\right)$ in sea ice of Stns A to D
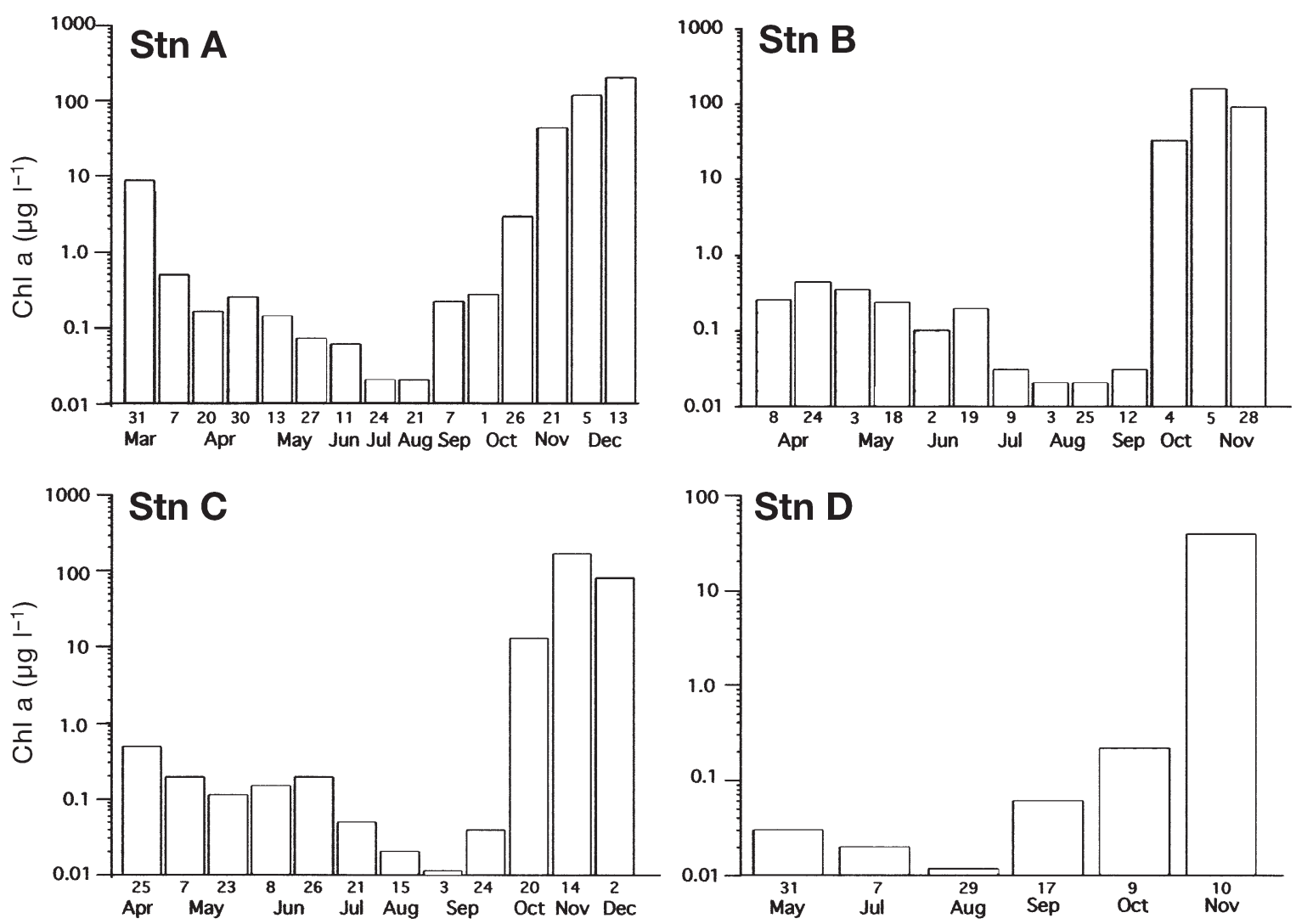

Fig. 3. Chlorophyll a concentrations $\left(\mu \mathrm{g}^{-1}\right)$ in the surface underlying water at Stns A to D 

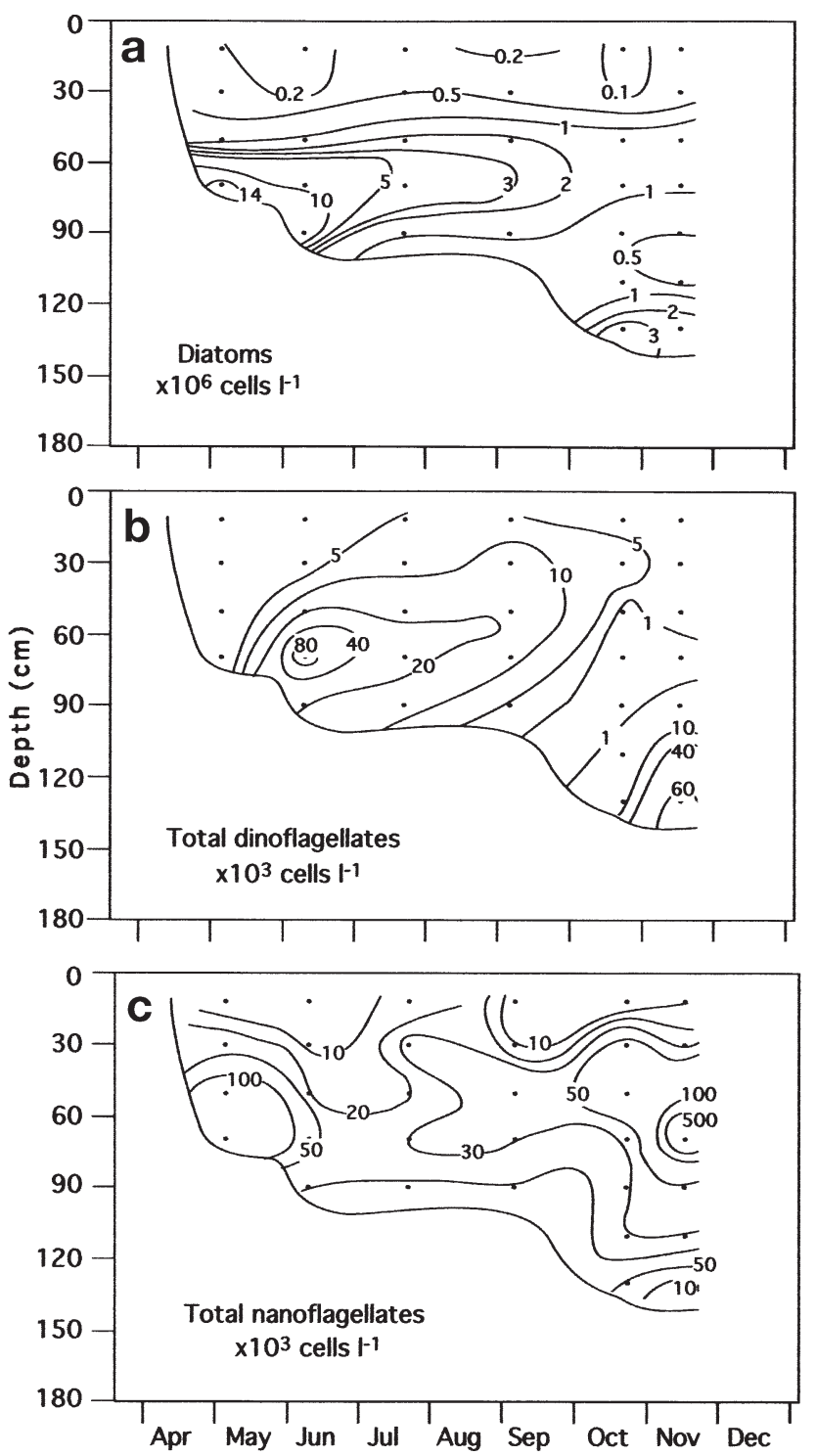

Fig. 4. Vertical distributions of (a) diatoms $\left(\times 10^{6}\right.$ cells $\left.\mathrm{l}^{-1}\right)$, (b) total dinoflagellates $\left(\times 10^{3}\right.$ cells $\left.\mathrm{l}^{-1}\right)$, (c) total nanoflagellates $\left(\times 10^{3}\right.$ cells $\left.^{-1}\right)$ in sea ice of Stn $C$ from May to late November

face stratum, these 2 species formed together 70 to $80 \%$ of diatoms. They were absent from lower ice levels, or contributed less than 1\%. Navicula glaciei formed 7 to $33 \%$ of the cells in the 0 to $40 \mathrm{~cm}$ stratum. Small young cells and spores of Corethron made up about $12 \%$ of diatoms in October at 20 to $80 \mathrm{~cm}$; Nitzschia subcurvata was present from July to November in the 20 to $140 \mathrm{~cm}$ ice core stratum, forming 1 to $8.6 \%$ of the cells. Chaetoceros dichaeta and Pseudonitzschia prolongatoides were encountered (4 to 8 and $12 \%$, respectively) between 40 and $80 \mathrm{~cm}$. Some species, e.g. Nitzschia stellata, appeared in abundance in June (60 to $80 \mathrm{~cm}$ : $2.0 \times 10^{5}$ cells $^{-1}$ ) and in July (80 to
$100 \mathrm{~cm}: 7.4 \times 10^{4}$ cells $\mathrm{l}^{-1}$ ). Synedropsis sp. and Tropidoneis sp. contributed 9 to $23 \%$ of the cells at the bottom of the ice in October and November (3.7 to $5.5 \times 10^{5}$ cells $\mathrm{l}^{-1}$ ). Other species found sporadically included Thalassiosira spp., Fragilariopsis kerguelensis, Pseudonitzschia turgidula, P. lineola/barkleyi, P. heimii, Planktoniella sp., Nitzschia taeniiformis, Eucampia sp., Dactyliosolen antarcticum, Cocconeis sp. Spores of Nitzschia and Corethron spp. (6 to $9 \%$ of diatoms) were found in October, and of the latter species in July in the surface layer. Dinoflagellates observed in June, July, September and October, included the cells and spores of the heterotrophic Gyrodinium spp., Gymnodinium spp., and autotrophic Prorocentrum spp.; in November there were the cells and spores of Prorocentrum spp. and heterotrophic Protoperidinium spp..

Throughout the ice period, total protozoan abundance, including total ciliates, dinoflagellates, euglenoids and heliozoa, ranged from $10^{3}$ to $80 \times 10^{3}{\text { cells } 1^{-1}}^{-1}$ (Fig. 6). Two maxima were observed, one at Stns A and $\mathrm{C}$ in April-May and at Stn D in July and, the other at Stns A and C in August-September. Maximum cell numbers decreased from $80 \times 10^{3}$ cells $\mathrm{l}^{-1}$ at the coastal Stn A to 15 to $20 \times 10^{3}$ cells $\mathrm{l}^{-1}$ at the offshore Stns C and D. At Stn D, except a maximum of $15 \times 10^{3}$ cells $1^{-1}$ in the ice bottom in July, total protozoan cell numbers were $<2 \times 10^{3}$ cells $1^{-1}$ throughout the ice period. The protozoan assemblage was mainly dominated by ciliates during the first maximum (Fig. 6). They contributed more than $75 \%$ of the total protozoan numbers during April-May at Stns A and C. At the 3 stations, ciliate assemblages were mainly dominated by 10 to $90 \mu \mathrm{m}$ sized unidentified species. Small quantities of Tintinnidae (Codonellopsis spp., Cymatocylis spp., Laackmanniella spp.), Strombididae (Strombidium spp.) and Strobilidiidae (Strobilidium spp.) were also encountered. Heterotrophic euglenoids were numerically the second component of the protozoan communities in April-May at Stns A and C (data not shown). On the other hand, they were the major component of the cell maxima observed in July at Stn D between 60 and $100 \mathrm{~cm}$ and in September at 20 to $40 \mathrm{~mm}$ at Stns A and C. Heterotrophic dinoflagellates were either not found, or present in only small numbers at the 3 stations. Heliozoa were absent, except at Stn A in December at 20 to $40 \mathrm{~cm}\left(78 \times 10^{3}\right.$ cells $\left.\mathrm{l}^{-1}\right)$. Adult copepods were absent and copepod nauplii were scarce. Large quantities of unidentified cysts were present in the ice cores throughout the study period.

There were no significant differences between the abundance of total culturable bacteria and mean cell volumes distribution observed at the 4 stations. The general seasonal patterns found for these 2 parameters were similar to those previously reported (Delille et al. 

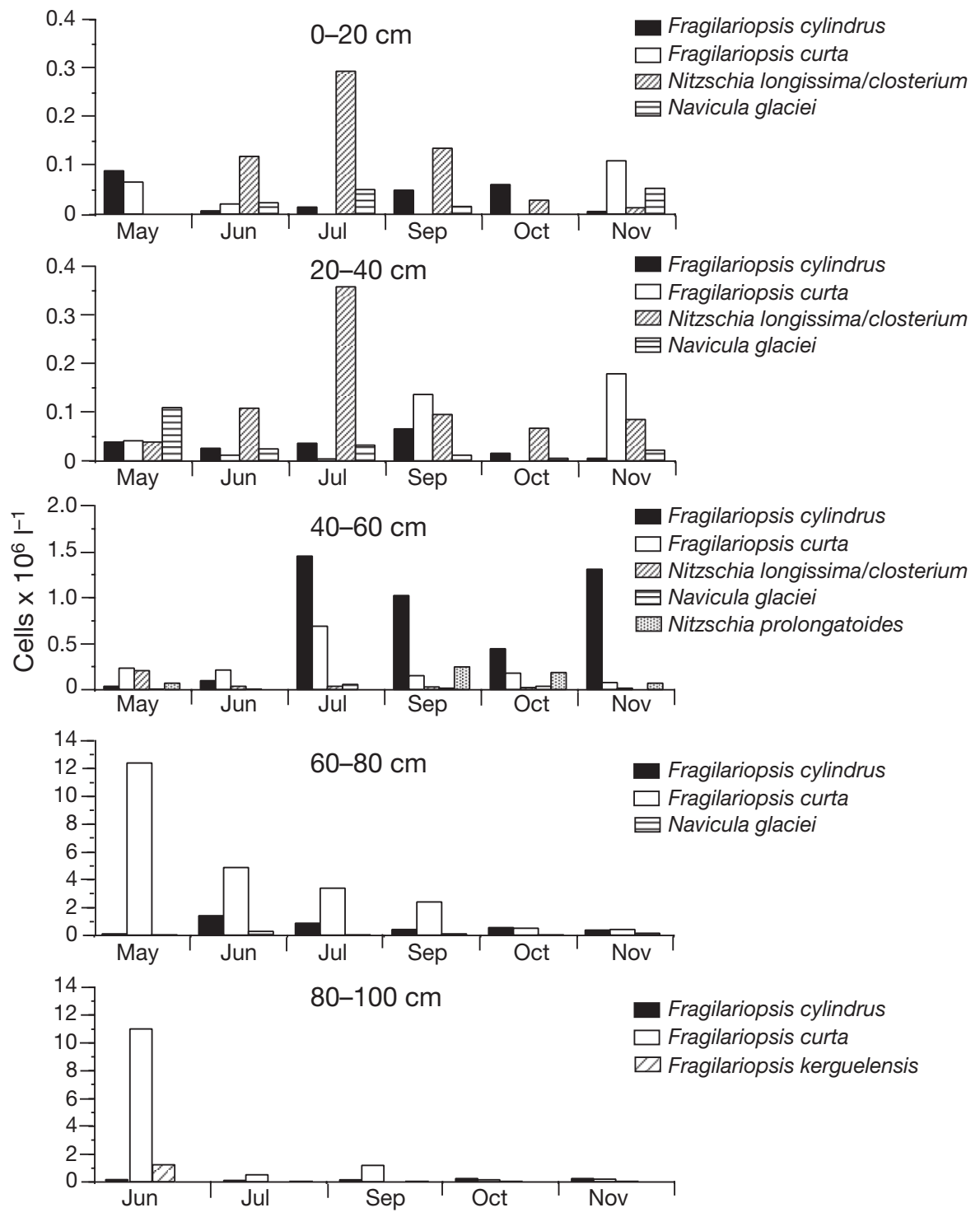

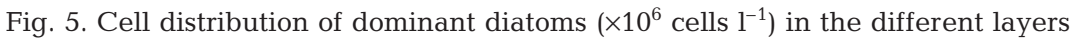
between surface and bottom sea ice of Stn C

2002, data not shown). In contrast, there was a clear decreasing gradient of culturable bacteria from the near-shore Stn A to the offshore Stn D (Fig. 7). Maximal levels of bacteria abundance were detected during ice formation and just before the summer thaw. However, both autumn and spring maximal values observed at Stn A were severely reduced at the offshore stations. Autumn values higher than $10^{7} \mathrm{CFU}^{-1}$, which were recorded until July at Stn A, fade in May at Stn B and were never recorded at Stn D. In the same way, spring abundance of bacteria, which could be higher than $2 \times 10^{7} \mathrm{CFU} \mathrm{l}^{-1}$ in surface layer of Stn A in November/December, was never higher than $2 \times 10^{6}$ $\mathrm{CFU}^{-1}$ in similar layers of Stns C and D.

\section{DISCUSSION}

We observed seasonal and spatial changes in the autotrophic biomass distribution. At the 4 stations, 2 peaks of chl a concentrations were found during the study period. The higher one occurred in the surface layer during the ice formation in AprilMay. The second one was observed in the bottom layer, just before ice break-up. Maximum chl a values (>200 $\mathrm{mg} \mathrm{m}^{-3}$ ) recorded at the coastal Stn A in April were similar to those observed in the first year fast ice in other Antarctic areas (Gunther \& Dickman 1999), but they were less than those found by Palmisano \& Sullivan (1983) and Watanabe et al. (1990). The seasonal distribution of autotrophic biomass was in accordance with that recorded previously in the same area. However, the maximum values of chl a recorded in this study at Stn A were about 4 to 5 times as high as those observed at the same station in 1993 and 1997 (Fiala \& Delille 1999, Delille et al. 2002). A decrease in chl a concentration was observed from south to north. Mean chl a values decreased dramatically from the near-shore Stn A to the offshore Stn D. The highest chl a levels observed in surface layer during autumn could be attributed to mechanical inclusion and concentration of microalgae into the newly formed sea ice and also to in situ growth (Stewart \& Fritsen 2004). During ice formation, a high level of biomass in the ice surface layer corresponds to a high level of phytoplankton biomass in sea water (Watanabe et al. 1990). In our study, sea-ice algal biomass can be $>20$ times higher than in the interface water. As observed at Stn A the highest chl a concentration $\left(8.8 \mu \mathrm{g} \mathrm{l}^{-1}\right)$ in the surface underlying water corresponded to a maximum chl a concentration $\left(200 \mu \mathrm{g} \mathrm{l}^{-1}\right)$ in sea ice. The second chl a biomass increase observed in the ice bottom layer in OctoberNovember just before ice-breakup was lower than that observed during the autumn. Such spring biomass increases have been previously reported (Palmisano \& Sullivan 1983, Garrison et al. 1987, Watanabe et al. 1990, Syvertsen \& Kristiansen 1993, Stoecker et al. 1998). A concomitant increase of chl a biomass in the 


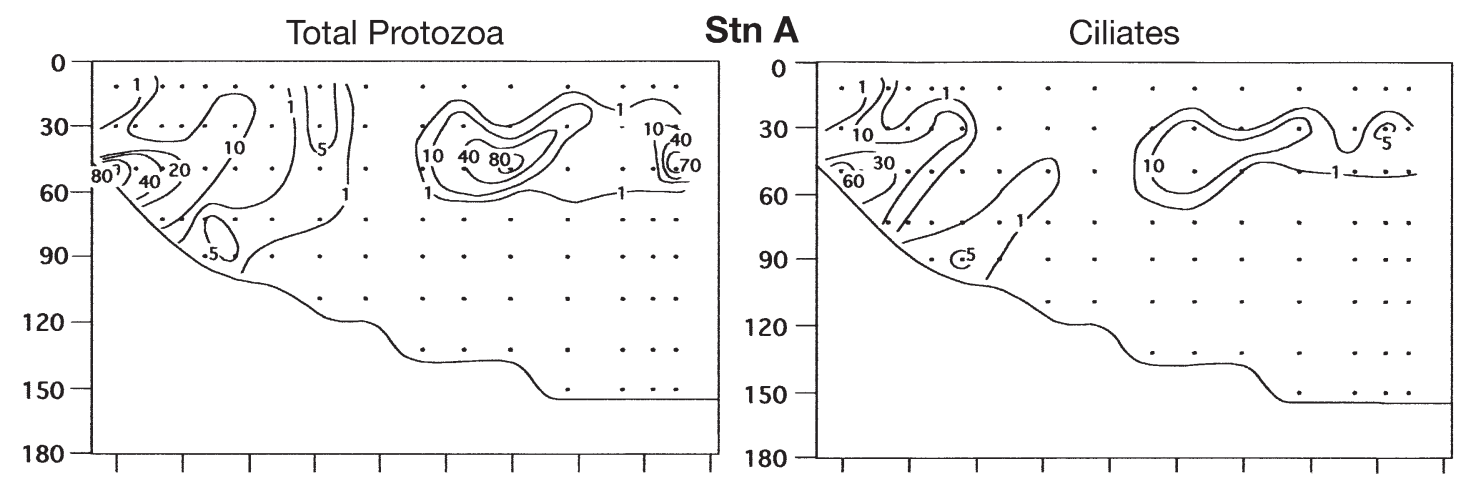

Stn C
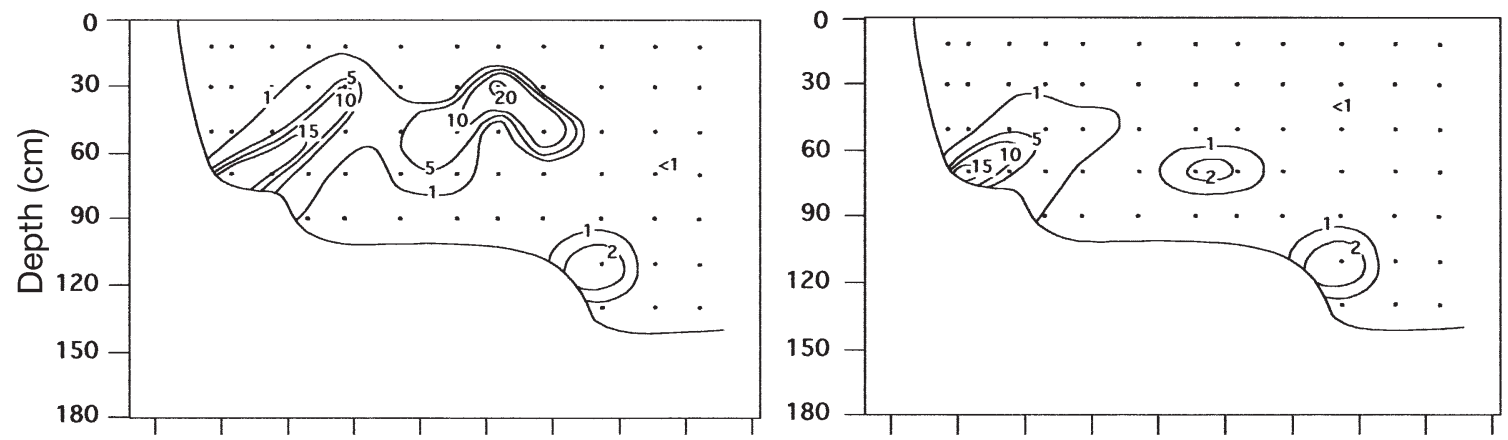

Stn D
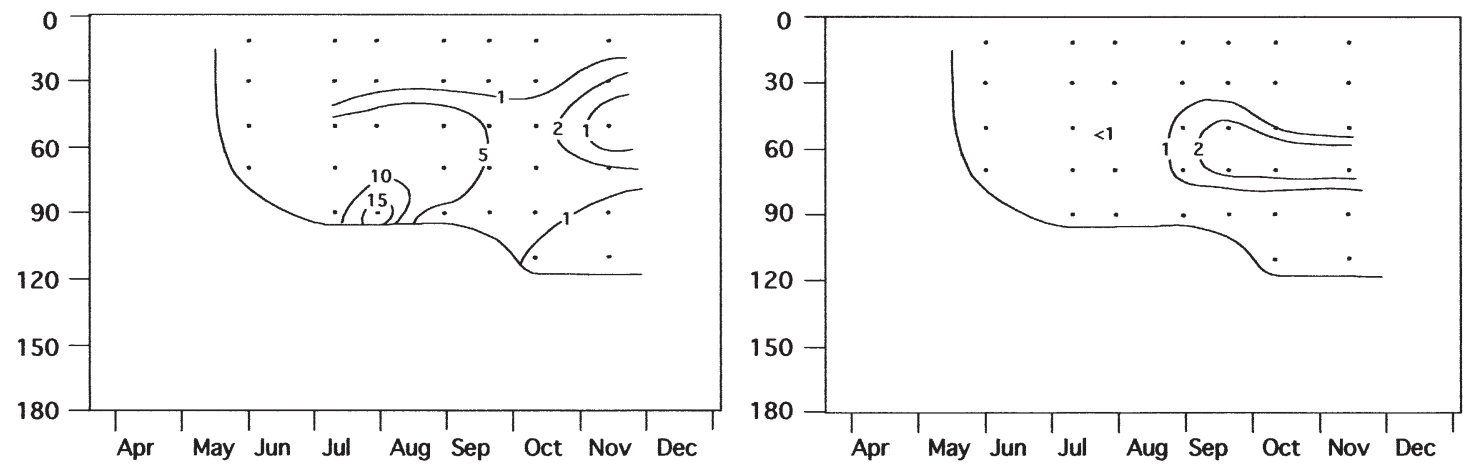

Fig. 6. Vertical distributions of total Protozoa $\left(\times 10^{3}\right.$ cells $\left.^{-1}\right)$ and heterotrophic ciliates $\left(\times 10^{3}\right.$ cells $\left.1^{-1}\right)$ in sea ice of Stns A, C and D

sea ice and in the underlying surface water during this period was observed. Unfortunately, underlying water species were not determined and it is not possible to know if the 2 communities were similar or different. Generally, the communities in fast ice are quite different from those of the underlying water (Palmisano \& Sullivan 1983, Riaux-Gobin et al. 2003), and would not provide an algal inoculation for a spring phytoplankton bloom (Palmisano \& Sullivan 1983, McMinn 1996). The south-north positive gradient in nitrate and silicic acid concentration clearly reflected a link with ice algal biomass. During the autumn bloom silicic concentration was low in the ice surface layer $(<25 \mu \mathrm{M}$ at Stn A) suggesting its uptake by diatoms. At all 4 study stations, algal ice communities were dominated by diatoms.
Dominance of diatoms and especially of the pennates is a common feature which has been observed elsewhere in Antarctic coastal sea ice (Grossi \& Sullivan 1985, Medlin \& Hasle 1990, Watanabe et al. 1990, Archer et al. 1996, McMinn 1996). Dominant diatoms showed a vertical zonation along the ice column, a pattern observed also at other Antarctic localities, such as in the sea ice at Lutzholm Bay (Hoshiai 1977), or in bottom congelation ice community at McMurdo Sound (Grossi \& Sullivan 1985). The presence of young cells of Fragilariopsis curta and F. cylindrus in May-June and also in September suggests 2 periods of these species reproduction. They were followed by an abundance of empty frustules in July and in OctoberNovember, providing further evidence for earlier 

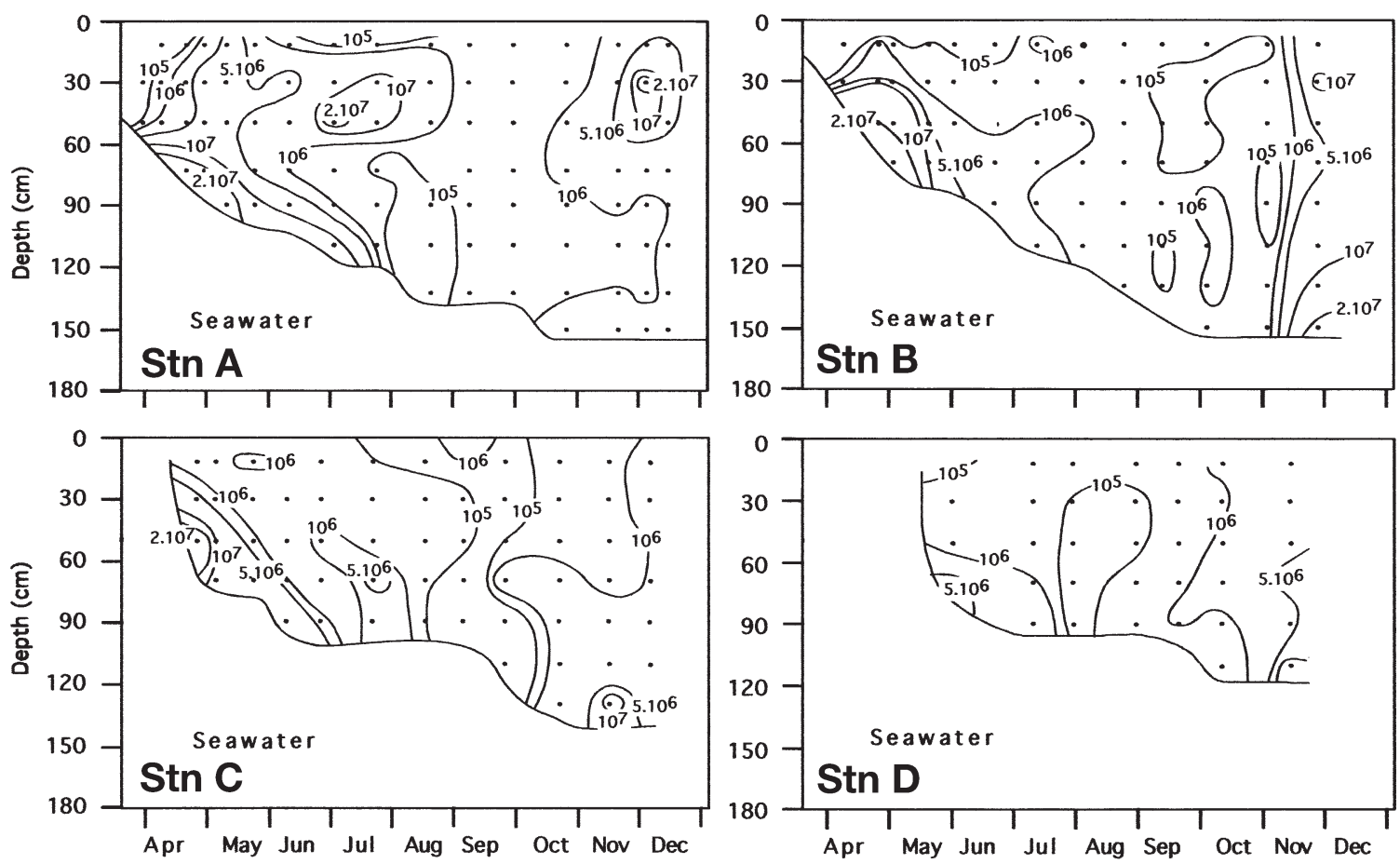

Fig. 7. Vertical distribution of culturable bacteria $\left(\mathrm{CFU}^{-1}\right)$ in sea ice of Stns A to D

reproduction and/or grazing by micro-heterotrophs. Seasonality of ice diatom distribution, both in terms of cell abundance and vertical occurrence, has also been reported from other Antarctic areas (Grossi et al. 1984). Apparently, algal ice assemblages may differ substantially depending on the type of ice (Scott et al. 1994), and the mode of ice formation (Clarke \& Ackley 1984, Spindler et al. 1990). The dominant species, F. curta and $F$. cylindrus, found in the present study in the fast ice were also reported prevalent in both, fast ice and pack ice around Prydz Bay (Scott et al. 1994). These are planktonic species found in highest abundance in offshore and coastal Antarctic waters (Hasle 1969, Kopczyńska et al. 1986). Their highest numbers in the bottom part of the ice column in May, June and July suggest their entrapment from a bloom in water beneath the ice, although they apparently multiply successfully within the ice. Another species, Nitzschia stellata, very common in the bottom ice in July was first described from Adélie Land area (Manguin 1957), and its occurrence there was confirmed by Medlin \& Hasle (1990). Vertical distribution of these species, which attain the highest concentrations at the bottom of the ice column, seem to be mainly controlled by the availability of nutrients in the underlying water (Grossi \& Sullivan 1985). In contrast, Nitzschia closterium/ $N$. longissima and Navicula glaciei, which dominate the less dense upper ice (10 to $20 \mathrm{~cm}$ ) diatom assemblage, probably require higher light conditions than other species for growth in the ice, as was suggested for the latter species by Whitaker (1977).

During the study period, distribution of culturable bacteria paralleled chl a distribution with maxima during autumnal sea ice formation and just before spring

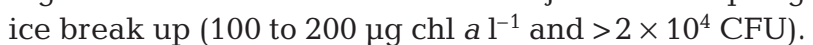
A clear decreasing gradient from the near-shore Stn A to the offshore Stn D was also observed. The good correlation between microalgal and bacterial abundance and biomass has been previously observed during spring and autumn in different Antarctic regions (Grossi et al. 1984, Lochte et al. 1997, Delille et al. 2002, Stewart \& Fritsen 2004). However, the strength of the coupling between microalgae and bacteria varies seasonally. Heterotrophic bacteria are reliant on microalgae for their energy supply through dissolved organic matter that is provided from algae via processes including degradation of cells (Riemann \& Sondergaard 1986), extracellular release (Suttle et al. 1991) and production of exopolymeric substances (Meiners et al. 2004). It has been suggested that, during the spring and autumn algal blooms, high levels of dissolved organic matter are available for bacterial consumption (Grossi et al. 1984, Fritsen \& Sullivan 1999, Stewart \& Fritsen 2004). In contrast, during winter, algal biomass is low and consequently, the low dissolved organic matter available limits the bacterial growth. During winter, the very low temperature of sea ice could also exert a strong control on bacterial 
growth by the way of a decrease of substrate assimilation (Nedwell 1999, Stewart \& Fritsen 2004). It has been suggested that during ice formation a differential trapping of bacteria and microalgae from sea water may also influence the bacteria-algae association in the pack ice (Stewart \& Fritsen 2004).

Large amounts of algal and bacterial biomass observed during the blooms provide an important food source for other microbial consumers, predominantly protozoans. Among heterotrophic protozoan communities, nanoflagellates and dinoflagellates can be the major contributors to the biomass in fast ice (Archer et al. 1996). In this study, heterotrophic dinoflagellates accounted for less than $25 \%$ of the total protozoan numbers, and protozoan communities were usually dominated by ciliates. Although few studies address the abundance, biomass and distribution of Antarctic ciliates, their contribution in the sea ice biota has been recognized (Gradinger et al. 1999, Scott et al. 2001). Their concentrations are generally higher than in the underlying waters and may reach more than $70 \%$ of the total protozoan biomass (Burkill et al. 1995). In the present study, the ciliate numbers were lower and the autotrophic biomass was higher than that recorded in the previous study in the same area (Delille et al. 2002). Although it is difficult to relate abundance estimates to grazing impact, low ciliate numbers coupled with high autotroph biomass during this study are probably indicative of a lower grazing pressure than in the previous study. The highest ciliate numbers associated with maximum abundance of bacteria and microalgae observed during the fall ice formation suggests a mechanical trapping and concentration of these 3 components into the newly formed ice. Heterotrophic euglenoids were dominant in the ice surface layer of Stns A and B in September and in ice bottom layer of Stn D in July. Although they are not generally regarded as a major component of the heterotrophic biomass (Garrison \& Buck 1989), they could contribute more than $50 \%$ of the heterotrophic biomass at certain times in the bottom and interior of the coastal sea ice (Archer et al. 1996). In ice samples low abundance of metazoa, dominated by copepods nauplii, suggests that their role in grazing effect was negligible.

Beside differences in the vertical distribution occurring over a very short distance $(<1 \mathrm{~m})$, a clear spatial heterogeneity from inshore to offshore in the different sympagic biota distribution was observed. A dramatic decrease occurred from south to north in the algal biomass. A similar gradient in chl a concentrations was reported in the same area by Riaux-Gobin et al. (2000). During ice formation, planktonic algae are physically concentrated by frazil ice, which affects results in chl a values in the newly formed ice. Evidence of algal biomass enrichment is provided in ice cores of Stns A, B and $\mathrm{C}$, during autumnal ice formation. Among the different factors controlling algal concentration in new ice, the date of ice formation is one of the most important (Fritsen \& Sullivan 1999, Stewart \& Fritsen 2004). In our study, the date of ice formation varied from the beginning of April at the coastal station to May at the offshore station. This could explain the south-north decrease of the underlying water phytoplankton biomass available for incorporation in the newly formed ice (from $8.8 \mu \mathrm{g} \mathrm{chl} \mathrm{a} \mathrm{l^{-1 }}$ at Stn A, to $0.03 \mu \mathrm{g} \mathrm{l}^{-1}$ at Stn D). This spatial decrease of the ice-incorporated algal biomass may affect the bacteria development by way of a decrease of the algal-derived inorganic substrate.

Acknowledgements. This work was supported by the French Polar Institute (IPEV) and the CNRS (UMR 7621). The research was partly financed by the Polonium Program of scientific cooperation between Poland and France. Special thanks are due to Y. Merloz for his contribution to the field work. The comments of 3 anonymous reviewers greatly assisted in improving this manuscript.

\section{LITERATURE CITED}

Ackley SF, Sullivan CW (1994) Physical controls on the development and characteristics of Antarctic sea ice biological communities - a review and synthesis. Deep-Sea Res 41:1583-1604

Ackley SF, Buck KR, Tagushi S (1979) Standing crop of algae in the sea ice of the Weddell Sea region. Deep-Sea Res 26A:268-281

Archer SD, Leakey RJG, Burkill PH, Sleigh MA, Appleby CJ (1996) Microbial ecology of sea ice at a coastal Antarctic site: community composition, biomass and temporal change. Mar Ecol Prog Ser 135:179-185

Becquevort S, Menon P, Lancelot C (2000) Differences of the protozoan biomass and grazing during spring and summer in the Indian sector of the Southern Ocean. Polar Biol 23:309-320

Bowman JP, McCammon SA, Brown MV, Nichols DS, McMeekin TA (1997) Diversity and association of psychrophilic bacteria in Antarctic sea ice. Appl Environ Microbiol 63:3068-3078

Brown MV, Bowman JP (2001) A molecular phylogenic survey of sea-ice microbial communities (SIMCO). FEMS Microbiol Ecol 35:267-275

Burkill PH, Edwards ES, Sleigh MA (1995) Microzooplankton and their role in controlling phytoplankton growth in the marginal ice zone of the Bellingshausen Sea. Deep-Sea Res 42:1277-1290

Caron DA, Dennett MR, Lonsdale DJ, Moran DM, Shalapyonok L (2000) Microzooplankton herbivory in the Ross Sea, Antarctica. Deep-Sea Res II 47:3249-3272

Clarke DB, Ackley SF (1984) Sea ice structure and biological activity in the Antarctic marginal ice zone. J Geophys Res 89:2087-2095

Delille D, Bouvy M (1989) Bacterial responses to natural organic inputs in marine sub-Antarctic area. Hydrobiologia 182:225-238

Delille D, Fiala M, Kuparinen J, Kuosa H, Plessis C (2002) Seasonal changes of microbial biomass in the first-year ice of Terre Adélie area (Antarctica). Aquat Microb Ecol 28:257-265 
Fiala M, Delille D (1999) Annual changes of microalgae biomass in Antarctic sea ice contaminated by crude oil and diesel fuel. Polar Biol 21:391-396

Fritsen CH, Sullivan CW (1999) Distributions and dynamics of microbial communities in the pack ice of the western Weddell Sea, Antarctica. In: Battaglia B, Valencia J, Walton DWH (eds) Antarctic communities. Species, structure and survival. Cambridge University Press, Cambridge, p 101-106

Garrison DL, Buck KR (1989) The biota of Antarctic pack ice in the Weddell Sea and Antarctic Peninsula regions. Polar Biol 10:211-219

Garrison DL, Buck KR (1991) Surface-layer sea ice assemblages in Antarctic pack ice during the austral spring: environmental conditions, primary production and community structure. Mar Ecol Prog Ser 75:161-172

Garrison DL, Buck KR, Fryxell GA (1987) Algal assemblages in Antarctic pack ice and ice-edge plankton. J Phycol 23: 564-572

Garrison DL, Buck KR, Gowing MM (1993) Winter plankton assemblage in the ice edge zone of the Weddell and Scotia Seas: composition, biomass and spatial distribution. Deep-Sea Res I 40:311-338

Garrison DL, Gibson A, Coale SL, Gowing MM, Okolodkov YB, Fritsen CH, Jeffries MO (2005) Sea-ice microbial communities in the Ross Sea: autumn and summer biota. Mar Ecol Prog Ser 300:39-52

Gozink JJ, Woese CR, Staley JT (1998) Polaribacter gen. nov., with three new species, $P$. irgensii sp. nov., $P$. franzmanii sp. nov., and $P$. filamentus sp. nov., gas vacuolate polar marine bacteria of the Cytophaga/Flavobacterium/Bacteroides group and reclassification of Flectobacillus glomeratus' as Polaribacter glomeratus comb. nov. Int J Syst Bacteriol 48:223-235

Gradinger R, Friedrich C, Spindler M (1999) Abundance biomass and composition of the sea ice biota of the Greenland Sea pack ice. Deep-Sea Res 46:1457-1472

Grossi SM, Sullivan CW (1985) Sea ice microbial communities.V. The vertical zonation of diatoms in an Antarctic fast ice community. J Phycol 21:401-409

Grossi SM, Kottmeier ST, Sullivan CW (1984) Sea ice microbial communities. III. Seasonal abundance of microalgae and associated bacteria, McMurdo Sound, Antarctica. Microb Ecol 10:231-242

Günther S, Dieckmann GS (1999) Seasonal development of algal biomass in snow-covered fast ice and the underlying platelet layer in the Weddell Sea, Antarctica. Antarct Sci 11:305-315

Hasle GR (1969) An analysis of the phytoplankton of the Pacific Southern Ocean: abundance composition and distribution during the Brategg Expedition, 1947-1948. Hvalradets Skrifter 52:1-169

Hobbie JE, Daley RJ, Jasper S (1977) Use of nuclepore filters for counting bacteria by fluorescence microscopy. Appl Environ Microbiol 33:1225-1228

Horner RA, Syvertsen EE, Thomas DP, Lange C (1988) Proposed terminology and reporting units for sea ice algal assemblages. Polar Biol 8:249-253

Horner R, Ackley SF, Dieckmann GS, Gulliksen B and 6 others (1992) Ecology of sea ice biota 1. Habitat, terminology, and methodology. Polar Biol 12:417-427

Hoshiai T (1977) Seasonal change of ice communities in the sea ice near Syowa Station, Antarctica. In: Dunbar MJ (ed) Polar oceans. Arct Inst North Am, Calgary, p 307-317

Junge K, Gosink JJ, Hoppe HG, Staley JT (1998) Arthrobacter, Brachybacterium and Planococcus isolates identified from Antarctic sea ice brine-description of Planococcus moneekinii. Syst Appl Microbiol 21:306-314

Kopczyńska EE, Weber LH, El-Sayed SZ (1986) Phytoplankton species composition and abundance in the Indian Sector of the Antarctic Ocean. Polar Biol 6:161-169

Legendre L, Ackley SF, Dieckmann GS, Gulliksen B and 6 others (1992) Ecology of sea ice biota. 2. Global significance. Polar Biol 12:429-444

Lotche K, Bjørnsen PK, Giesenhagen H, Weber A (1997) Bacterial standing stock and production and their relation to phytoplankton in the Southern Ocean. Deep-Sea Res II 44:321-340

Manguin E (1957) Premier inventaire des diatomées de la Terre Adélie antarctique. Espèces nouvelles. Rev Algol 3:111-134

Maykut GA (1985) The ice environment. In: Horner R (ed) Sea ice biota. CRC Press, Boca Raton, FL, p 21-82

McMinn A (1996) Preliminary investigation of the contribution of fast-ice algae to the spring phytoplankton bloom in Ellis Fjord, eastern Antarctica. Polar Biol 16:301-307

Medlin LK, Hasle GR (1990) Some Nitzschia and related diatom species from fast ice samples in the Arctic and Antarctic. Polar Biol 10:451-479

Meiners K, Brinkmeyer R, Granskog MA, Lindfors A (2004) Abundance, size distribution and bacterial colonization of exopolymer particles in Antarctic sea ice (Bellingshausen Sea). Aquat Microb Ecol 35:283-296

Moro I, Paccagnella R, Barbante C, Andreoli C (2000) Microalgal communities of the sea ice, ice-covered and ice-free waters of Wood Bay (Ross Sea, Antarctica) during the austral summer 1993-94. PSZN I: Mar Ecol 21:233-245

Nedwell DB (1999) Effect of low temperature on microbial growth: lowered affinity for substrates limits growth at low temperature. FEMS Microbiol Ecol 30:101-111

Neveux J, Panouse M (1987) Spectrofluorometric determination of chlorophylls and pheophytins. Arch Hydrobiol 109:567-581

Nichols D, Bowman J, Sanderson K, Mancuso Nichols C, Lewis T, McMeekin T, Nichols PD (1999) Developments with Antarctic microorganisms: culture collections, bioactivity screening, taxonomy, PUFA production and coldadapted enzymes. Curr Opin Biotechnol 10:240-246

Oppenheimer CH, ZoBell CE (1952) The growth and viability of sixty-three species of marine bacteria as influenced by hydrostatic pressure. J Mar Res 11:10-18

Palmisano AC, Sullivan CW (1983) Sea ice microbial communities (SIMCO) I. Distribution, abundance and primary production of ice microalgae in McMurdo Sound, Antarctica in 1980. Polar Biol 2:171-177

Reddy GSN, Raghavan PUM, Sarita NB, Prakash JSS, Nagesh N, Delille D, Shivaji S (2002) Halomonas glaciei sp. nov. isolated from fast ice of Adelie Land, Antarctica. Extremophiles 7:55-61

Rheinheimer G, Gocke K, Hoppe HG (1989) Vertical distribution of microbiological and hydrographic-chemical parameters in different areas of the Baltic Sea. Mar Ecol Prog Ser 52:55-70

Riaux-Gobin C, Tréguer P, Poulin M, Vétion G (2000) Nutrients, algal biomass and communities in land-fast ice and seawater off Adélie Land (Antarctica). Antarct Sci 12: 160-171

Riaux-Gobin C, Poulin M, Prodon R, Tréguer P (2003) Landfast microalgal and phytoplanktonic communities (Adélie Land, Antarctica) in relation to environmental factors during ice break-up. Antarct Sci 15:353-364

Riemann B, Sondergaard GA (1986) Regulation of bacterial secondary production in two eutrophic lakes and in experimental enclosures. J Plankton Res 8:519-536 
Scott FJ, Davidson AT, Marchant HJ (2001) Grazing by the Antarctic sea-ice ciliate Pseudocohnilembus. Polar Biol 24: 127-131

Scott P, McMinn A, Hosie G (1994) Physical parameters influencing diatom community structure in eastern Antarctic sea ice. Polar Biol 14:507-517

Song W, Wilbert N (2000) Ciliates from Antarctic sea ice. Polar Biol 23:212-222

Spindler M, Dieckmann GS, Lange MA (1990) Seasonal and geographic variations in sea ice community structure of the Weddell Sea, Antarctica. In: Kerry KR, Hempel G (eds) Antarctic ecosystems. Springer-Verlag, Berlin, p 129-135

Stewart FJ, Fritsen CH (2004) Bacteria-algae relationships in Antarctic sea ice. Antarct Sci 16:143-156

Stoecker DK, Buck KR, Putt M (1993) Changes in the sea-ice brine community during spring-summer transition, McMurdo Sound, Antarctica. II. Phagotrophic protists. Mar Ecol Prog Ser 95:103-113

Stoecker DK, Gustafson DE, Merrel JR, Black MMD, Baier CT (1997) Excystment and growth of chrysophytes and dinoflagellates at low temperatures and high salinities in Antarctic sea-ice. J Phycol 33:585-595

Stoecker DK, Gustafson DE, Black MMD, Baier CT (1998) Population dynamics of microalgae in the upper land-fast sea ice at a snow-free location. J Phycol 34:60-69

Stoecker DK, Gustafson DE, Baier CT, Black MMD (2000) Primary production in the upper sea ice. Aquat Microb Ecol

Editorial responsibility: David A. Caron,

Los Angeles, California, USA
$21: 275-287$

Suttle CA, Chan AM, Fuhrman JA (1991) Dissolved free amino acids in the Sargasso Sea: uptake and respiration rates, turnover times, and concentrations. Mar Ecol Prog Ser 70:189-199

Syvertsen EE, Kristiansen S (1993) Ice algae during EPOS, leg 1: assemblages, biomass, origin and nutrients. Polar Biol 13:61-65

Tréguer P, Le Corre P (1975) Manuel d'analyses des sels nutritifs dans l'eau de mer. Utilisation de l'AutoAnalyzer II. Document UBO, Brest

Utermöhl H (1958) Zur Vervollkommnung der quantitativen Phytoplankton-Methodik Mitt Int Verein Theor Angew Limnol 9:1-38

Vaqué D, Agusti S, Duarte CM (2004) Response of bacterial grazing rates to experimental manipulation of an Antarctic coastal nanoflagellate community. Aquat Microb Ecol $36: 41-52$

Watanabe K, Satoh H, Hoshiai T (1990) Seasonal variation in ice algal assemblages in the fast ice near Syowa Station in 1983/84. In: Kerry KR, Hempel G (eds) Antarctic ecosystems. Ecological change and conservation. SpringerVerlag, Berlin, p 136-142

Whitaker TM (1977) Sea ice habitats of Signy Island (South Orkneys) and their primary productivity. In: Llano GA (ed) Adaptations within Antarctic ecosystems. Gulf Publishing, Houston, TX, p 75-82

Submitted: April 15, 2005; Accepted: December 16, 2005 Proofs received from author(s): April 4, 2006 